\title{
NADZÓR NAD DZIAŁALNOŚCIĄ SPÓŁKI WODNEJ
}

\section{SUPERVISION OF WATER LAW COMPANY}

\author{
http://dx.doi.org/10.12775/PPOS.2015.003
}

\section{STRESZCZENIE}

Spółka wodna jest jedną z najstarszych form organizacyjnych związanych z gospodarką wodną i rozwojem prawa wodnego. Spółki te, stanowiąc zrzeszenie osób fizycznych i prawnych, nie działają w celu osiągnięcia zysku, a ich celem jest zaspokajanie, wskazanych ustawą Prawo wodne, potrzeb w dziedzinie gospodarowania wodami. Spółki wodne jako podmioty zaangażowane w realizację zadań i celów publicznych poddane zostały nadzorowi administracyjnemu realizowanemu przez starostów. Nadzór ten polega na prawnie dopuszczonej możliwości podjęcia wobec spółki wodnej środków nadzorczych o charakterze kontrolnym lub korygującym. Środki o charakterze korygują-

Doktor nauk prawnych, Katedra Prawa Ochrony Środowiska Wydziału Prawa i Administracji Uniwersytetu Mikołaja Kopernika. 
cym stanowią władczą ingerencję organu nadzorczego w działalność spółki wodnej zmierzającą do usunięcia stanu niezgodnego z prawem. Poddanie spółki wodnej nadzorowi administracyjnemu, postrzegane przez przedstawicieli doktryny jako charakterystyczna cecha tej formy organizacyjno-prawnej, stanowi przejaw administracyjnoprawnej reglamentacji wolności zrzeszania się, wynikającej z ustawowych celów działalności spółki wodnej związanych z ich udziałem w gospodarowaniu wodami.

\section{Słowa kluczowe}

Nadzór; spółka wodna; środki nadzoru

\section{ABSTRACT}

A water law company is one of the oldest organizational forms connected with water resources management and development of water law. Water law companies being an association of natural and juridical persons do not operate with the aim of gaining a profit. Their foremost goal is the fulfillment of needs and provisions stipulated by the water law which concerns water resource management. Water law companies as public sector entities are subject to supervision exercised by Starosta (head of poviat). The supervision constitutes legally allowed supervisory measures of controlling and correctional nature which can be taken against a water law company. The supervisory measures of correctional nature are understood as an interference of a supervisory body in a company's activity with the aim of rectifying a state of matter that is incompatible with the principles of law. Putting a water law company under administrative supervision, which is regarded by representatives of the doctrine as a characteristic feature of this type of organizational and legal form, constitutes a sign of administrative and legal rationing of freedom of association which derives from a water law company's statutory objectives associated with its involvement in water resources management.

\section{Keywords}

Supervision; water law company; instruments of supervision. 


\section{WPROWADZENIE}

Spółka wodna jest jedną z najstarszych form organizacyjnych związanych z gospodarką wodną i rozwojem prawa wodnego ${ }^{1}$. Zgodnie z art. 164 ust. 1 p.w. ${ }^{2}$ spółki wodne oraz związki wałowe są formami organizacyjnymi, które nie działają w celu osiągnięcia zysku, zrzeszają osoby fizyczne lub prawne i mają na celu zaspokajanie wskazanych ustawą potrzeb w dziedzinie gospodarowania wodami. W doktrynie prawa administracyjnego spółkę wodną określa się jako gospodarczą organizację samorządową dla realizacji zadań gospodarki wodnej ${ }^{3}$, spółkę prawa administracyjnego ${ }^{4}$, czy też formę zbliżoną do przedsiębiorstw użyteczności publicznej ${ }^{5}$. W ocenie R. Paczuskiego spółka wodna jest instytucją prawnoustrojową, podlegającą przepisom prawa wodnego ${ }^{6}$. Stanowi ona podstawę organizacyjno-prawną wykorzystywania działań i inicjatyw społecznych do realizacji zadań administracji publicznej w dziedzinie gospodarki wodnej, poprzez utożsamianie realizacji celów i zadań spółki o charakterze publiczno-prawnym $\mathrm{z}$ interesem indywidualnym jej członków ${ }^{7}$. Spółka wodna, będąc dobrowolnym zrzeszeniem osób fizycznych i prawnych, stanowi organizację o charakterze celowym, przy czym cel ten jest prawnie zdeterminowany. Wyłącznym celem spółki wodnej jest zaspokojenie wskazanych ustawą potrzeb $\mathrm{w}$ dziedzinie gospodarowania wodami. Słusznie w związku z tym przyjmuje się, iż spółka wodna to podmiot prawa, utworzony przez osoby fizyczne i osoby prawne, w celu wykonywania zadań o charakterze publicznoprawnym,

1 R. Paczuski, Spótki wodne. Historia, prawne podstawy działania, nowe tendencje, Warszawa 1989, s. 11.

2 Ustawa z dnia 18 lipca 2001 r. Prawo wodne, tekst jedn. Dz.U. z 2015 r., poz. 469, zwana dalej prawo wodne lub określana skrótem p.w.

3 R. Paczuski, Spółki wodne - cele, zadania, prawne podstawy organizacji oraz perspektywy ich rozwoju w kontekście zachodzących zmian, Toruń 2006, s. 16.

4 J. Szachułowicz, Prawo wodne. Komentarz, Warszawa 2010, s. 404.

5 Ibidem, s. 353.

6 R. Paczuski, Spótka wodna - cele..., s. 11 i n.

7 Ibidem, s. 11. 
związanych z gospodarką wodną ${ }^{8}$. Zaangażowanie spółki wodnej w realizację zadań i celów publicznych oraz całkowite poddanie jej działalności regulacji administracyjnoprawnej stanowi ratio legis dla objęcia działalności spółki nadzorem administracyjnym. Nadzór ten realizowany jest przez organy administracji publicznej przy wykorzystaniu środków nadzorczych służących zapewnieniu zgodności z prawem działań podmiotu nadzorowanego. Wobec braku jednolitości poglądów doktryny co do istoty nadzoru administracyjnego oraz rozbieżności znaczeń terminu nadzór w tekstach prawnych szczególnie istotne, dla ustalenia rzeczywistego zakresu dopuszczalnej ingerencji administracji w sferę bieżącej działalności podmiotu nadzorowanego, jest dokonanie szczegółowej analizy przyjętych na gruncie prawa wodnego rozwiązań.

\section{POJĘCIE NADZORU}

Pojęcie nadzoru należy do jednych z podstawowych, a zarazem bardziej kontrowersyjnych pojęć nauki prawa administracyjnego. Jest to niewątpliwie pojęcie prawne, o bardzo zróżnicowanym kontekście znaczeniowym, co w sposób istotny pogłębia trudności w jednoznacznym ustaleniu jego treści. Jak słusznie zauważa M. Możdżeń-Marcinkowski, niezmiennie niekonsekwentne stanowisko ustawodawcy w kwestii nadzoru administracyjnego było i w dalszym ciągu jest dla nauki prawa administracyjnego źródłem swoistego dyskomfortu pojęciowego, ${ }^{9}$ o czym świadczy wielość i różnorodność określeń służących zdefiniowaniu nadzoru. Nadzór określany jest jako sytuacja ${ }^{10}$,

8 B. Rakoczy, [w:] Prawo wodne. Komentarz, red. B. Rakoczy, Lex 2013, wer. elektr.

9 M. Możdżeń-Marcinkowski, Nadzór właścicielski Skarbu Państwa w systemie kontroli administracji publicznej - zarys problematyki, [w:] Koncepcja systemu prawa administracyjnego, red. J. Zimmermann, Warszawa 2007, s. 317.

10 M. Wierzbowski, A. Wiktorowska, Podstawowe pojęcia teoretyczne $w$ nauce prawa administracyjnego, [w:] Polskie prawo administracyjne, red. J. Służewski, Warszawa 1992, s. 39. 
instytucja ${ }^{11}$, czynność ${ }^{12}$, funkcja ${ }^{13}$, a także właściwość organu ${ }^{14}$, uprawnienie organu ${ }^{15}$, możność oddziaływania, zespół kompetencji ${ }^{16}$, czy zespół instrumentów ${ }^{17}$. W doktrynie prawa administracyjnego podejmuje się również próby określenia zakresu nadzoru bez wyjaśniania jego istoty, poprzez wskazanie, iż nadzór oznacza kontrolę oraz możność podjęcia prawem przewidzianych środków wiążących nadzorowanego lub możność bezpośredniego wzruszenia (uchylenie, stwierdzenia nieważności jego) jego aktów ${ }^{18}$. W ocenie S. Jędrzejewskiego, przez pojęcie nadzór należałoby rozumieć zespół kompetencji organu do wywierania wpływu na podległe podmioty, niezależnie od stopnia i zakresu podległości, z czego wynikałby obowiązek sprawowania nadzoru ${ }^{19}$. Instytucja nadzoru administracyjnego bardzo mocno związana jest ze zdecentralizowanym modelem organizacji administracji ${ }^{20}$, co w ocenie części przedstawicieli doktryny uzasadnia pogląd, iż jest to instytucja ustrojowego prawa administracyjnego, która może być rozpatrywana wyłącznie w odnie-

11 L. Bar, Elementy administracyjne $w$ kierowaniu gospodarka narodowa, [w:] Instytucje prawne $w$ gospodarce narodowej, red. L. Bar, Warszawa 1981, s. 93.

12 Z. Rybicki, [w:] Z. Rybicki, S. Piątek, Zarys prawa administracyjnego i nauki administracji, Warszawa 1984, s. 263.

13 J. Służewski, [w:] T. Bocheński, S. Gebert, J. Służewski, Rady narodowe i terenowe organy administracji państwowej, Warszawa 1977, s. 259 i n.

14 W. Dawidowicz, Zagadnienia ustroju administracji państwowej w Polsce, Warszawa 1970, s. 34.

15 J. Homplewicz, Ogólne zagadnienia prawne kontroli administracji, „Kontrola Państwowa" 1965, Nr 4, s. 2.

16 T. Bigo, $Z$ problemów kontroli nad administracją terenowa, „Kontrola Państwowa" 1964, Nr 1, s. 2.

17 A. Jaroszyński, Nadzór nad radami narodowymi i administracją terenową, „Rada Narodowa, Gospodarka, Administracja” 1983, Nr 18, s. 17.

18 E. Ochendowski, Prawa administracyjne. Czesść ogólna, Toruń 2013, s. 237.

19 S. Jędrzejewski, Zakres pojęcia „nadzór” $w$ doktrynie prawa administracyjnego, [w:] Administracja publiczna u progu XXI wieku, przew. kom. red. Z. Niewiadomski, Przemyśl 2000, s. 280.

20 J. Starościak, Decentralizacja administracji, Warszawa 1960, s. 9-11; T. Rabska, Podstawowe pojęcia organizacji administracji, [w:] System prawa administracyjnego, t. I, red. J. Starościak, Wrocław 1977, s. 317 i n. 
sieniu do powiązań między podmiotami administracyjnymi ${ }^{21}$. W ocenie W. Dawidowicza, należy wykluczyć posługiwanie się pojęciem nadzoru w zewnętrznej sferze działania organów administracji, która jest normowana prawem administracyjnym i przyjąć, że w tym zakresie ustawowy termin „nadzór” oznacza $\mathrm{w}$ istocie rzeczy kompetencje organu do kontroli przestrzegania prawa przez podmiot uprawniony do określonego działania na mocy decyzji administracyjnej tego organu ${ }^{22}$. Odmienny pogląd prezentuje M. Szewczyk ${ }^{23}$, zdaniem którego nadzór jest kategorią za pomocą której można określić relacje wynikające z prawa materialnego i nie można traktować nadzoru w materialnym prawie administracyjnym (nadzór budowlany, nadzór weterynaryjny) jedynie jako „schemat myślowy”, ale jako realnie istniejącą instytucję. Wielość kontekstów posłużenia się pojęciem nadzór na gruncie prawa pozytywnego, skłania do uznania zasadności wyodrębnienia trzech podstawowych płaszczyzn analizy tego pojęcia: 1) układu scentralizowanego, 2) układu zdecentralizowanego oraz 3) sfery zewnętrznej administracji. W dwóch pierwszych obszarach pojęcie nadzoru odnosi się do zagadnień ustrojowych, organizacji aparatu administracyjnego. $\mathrm{W}$ trzecim przypadku, pojęcie to odpowiada relacji występującej ze względu na fakt obowiązywania normy materialnego prawa administracyjnego, pomiędzy różnymi podmiotami, z czego co najmniej jeden jest podmiotem administrującym ${ }^{24}$. Jak zauważa M. Szewczyk „przesłanką ze względu na którą mogą powstawać, ulegać zmianie, ustawać, wygasać i ulegać unieważnieniu materialne stosunki administracyjne $\mathrm{w}$ ramach relacji nadzoru - jest fakt ustanowienia przez ustawodawcę ochrony pewnych dóbr, istnienia hierarchii między nimi, jak i upoważnienia administracji do strzeżenia ich nienaruszalności oraz ustalonej miedzy nimi hierarchii, a także do użycia środków niezbędnych

21 Por. P. Rączka, Nadzór nad samorządem zawodowym, Toruń 1999, s. 106; J. Jagielski, Kontrola administracji publicznej, Warszawa 2006, s. 24.

22 W. Dawidowicz, Polskie prawo administracyjne, Warszawa 1978, s. 263.

23 M. Szewczyk, Nadzór w materialnym prawie administracyjnym, Poznań 1996, s. 12 i 17.

24 Por. D. Wacinkiewicz, Kontrola i nadzór w prawie komunalnym, Warszawa 2007, s. 215. 
do odsunięcia niebezpieczeństw im zagrażających"25. Należy jednocześnie zauważyć, iż koncepcja nadzoru w materialnym prawie administracyjnym nie wyczerpuje wszystkich relacji, expressis verbis nazwanych przez ustawodawcę nadzorem, odnoszących się do podmiotów spoza administracji publicznej. Przykładem takiej sytuacji może być administracyjny nadzór nad stowarzyszeniami, czy spółkami wodnymi. Nadzór, w tym przypadku, posiada bowiem wszelkie cechy nadzoru weryfikacyjnego, charakterystycznego dla zdecentralizowanych struktur administracji publicznej pomimo, iż odnosi się do podmiotów spoza administracji publicznej. Skala różnorodności sytuacji, w których ustawodawca posługuje się pojęciem nadzoru oraz wielość związanych z tym pojęciem rozbieżnych poglądów, skłania przedstawicieli doktryny do odstępowania od próby jednolitego określenia prawnego tego terminu, w szczególności traktowania nadzoru jako jednolitej prawnej instytucji ${ }^{26}$. Nie zwalania to jednak przedstawicieli nauki od poszukiwania koncepcji wyjaśniającej istotę nadzoru w prawie administracyjnym. Jedną z nich przedstawił S. Jędrzejewski, przyjmując iż nadzór $\mathrm{w}$ prawie administracyjnym to funkcja organu administracji publicznej, wyrażająca się w obowiązku czuwania nad zachowaniem innych podmiotów, przede wszystkim zachowaniem zgodnym z prawem ${ }^{27}$. Nadzór jako „obowiązek czuwania” występuje we wszystkich możliwych układach stosunków w sferze prawa administracyjnego, w różnych odmianach i w zależności od typu stosunku realizowany jest w różnych formach i za pomocą różnych środków prawnych ${ }^{28}$. W ocenie S. Jędrzejewskiego termin „nadzór” znamionuje tylko „obowiązek czuwania” nad kimś lub nad czymś i w takim właśnie znaczeniu ustawy posługują się tym terminem, a jaki w tym celu służy organowi zakres kompetencji, o tym stanowią przepisy szczegółowe ${ }^{29}$. Koncepcja

25 M. Szewczyk, op. cit., s. 71.

26 S. Jędrzejewski, op. cit., s. 288.

27 Ibidem, s. 292.

28 Ibidem, s. 290.

29 Ibidem, s. 290. Pogląd ten, w zakresie konieczności każdorazowego odwołania się do przepisów konkretnej regulacji prawnej, odpowiada stanowisku J. Bocia, iż nie ma jednego, wszechstronnie trafnego pojęcia nadzoru 
pojmowania nadzoru jako funkcji administracji jest szczególnie przydatna do analizy „nietypowych” stosunków nadzoru do których niewątpliwie należy nadzór nad spółką wodną.

\section{ZAKRES PODMIOTOWY, PRZEDMIOTOWY I KRYTERIA NADZORU NAD SPÓŁKĄ WODNĄ}

Zakres podmiotowy, przedmiotowy oraz kryteria nadzoru nad spółka wodną wyznaczają przepisy ustawy prawo wodne. Zgodnie z art. 178 p.w. nadzór nad działalnością spółek wodnych sprawuje starosta. Oznacza to, iż podmiotem nadzorowanym jest spółka wodna, a organem nadzorującym starosta, natomiast przedmiotem nadzoru - działalność spółki. Przepisy ustawy prawo wodne, regulujące nadzór nad spółkami wodnymi, nie określają expressis verbis właściwości miejscowej organów nadzoru. W literaturze przedmiotu wskazuje się, iż właściwość tę ustala się na podstawie siedziby spółki wodnej, w oparciu o art. 165 ust. 3 p.w. ${ }^{30}$ Przepis art. 165 p.w. odnosi się do prawnych uwarunkowań utworzenia spółki, a jego ust. 3 stanowi, iż starosta właściwy miejscowo dla siedziby spółki wodnej zatwierdza statut spółki w drodze decyzji administracyjnej. Odrębność instytucji zatwierdzenia statutu spółki, skutkującej rozpoczęciem bytu prawnego spółki wodnej jako osoby prawnej, oraz funkcji nadzoru nad działalnością spółki nakazuje zachowanie daleko idącej ostrożności w odwoływaniu się do przepisu art. 165 ust. 3 p.w. jako podstawy właściwości miejscowej organu nadzoru. Oczywiście przyjmując założenie racjonalności ustawodawcy, tożsamość podmiotowa organu zatwierdzającego statut spółki i organu nadzoru nad spółką jest ze wszech miar uzasadniona, nie mniej jednak wynikać ona powinna z wyrażonej w normie

i należy je za każdym razem budować na podstawie treści tych postanowień normatywnych, które regulują nadzór. Tegoż, Prawo administracyjne, red. J. Boć, Wrocław 1993, s. 140.

30 C. Kowalewski, [w:] Wybrane problemy prawa wodnego, red. B. Rakoczy, Lex 2013, wer. el. 
prawnej woli ustawodawcy, co należy podnosić jako wniosek de lege ferenda. Uważam, iż dla ustalenia właściwości miejscowej organu nadzoru nie mają zastosowania przepisy kodeksu postępowania administracyjnego ${ }^{31}$, pomimo przyjęcia przez ustawodawcę formy decyzji administracyjnej dla rozstrzygnięć nadzorczych. Stanowisko swoje wywodzę z faktu, iż nadzór nad spółką wodną jest procesem ciągłym, nieograniczonym ramami czasowymi postępowania administracyjnego. Wszczęcie tego postępowania i wydanie rozstrzygnięcia nadzorczego stanowi tylko pewien fragment ciągłej relacji nadzoru, który de facto w przypadku prawidłowego funkcjonowania spółki wodnej może się nigdy nie ziścić. Brak jest w związku z tym podstaw stosowania przepisów kodeksu postępowania administracyjnego o właściwości miejscowej organu do działań organu nie mających cech czynności procesowych, w rozumieniu tego kodeksu. Powierzenie kompetencji nadzorczych staroście, bez zastrzeżenia, iż wykonuje je jako zadania $\mathrm{z}$ zakresu administracji rządowej pozwala stwierdzić, iż nadzór nad działalnością spółek wodnych jest zadaniem własnym powiatu ${ }^{32}$. Powstaje w związku z tym pytanie o prawną dopuszczalność przeniesienia kompetencji $\mathrm{w}$ tym zakresie $\mathrm{w}$ drodze porozumienia. Zgodnie $\mathrm{z}$ art. 5 ust. 2 ustawy o samorządzie powiatowym ${ }^{33}$ powiat może zawierać porozumienia $\mathrm{w}$ sprawie powierzenia prowadzenia zadań publicznych z jednostkami lokalnego samorządu terytorialnego, a także z województwem, na którego obszarze znajduje się terytorium powiatu. Ustalenie, iż wykonywanie nadzoru nad spółkami wodnymi należy do zadań własnych powiatu realizowanych w drodze kompetencji przyznanych staroście pozwala przyjąć, iż dopuszcza się możliwość powierzenia wykonywania tego zadania lokalnym jednostkom samorządu terytorialnego

31 Ustawa z dnia 14 czerwca 1960 r. Kodeks postępowania administracyjnego, tekst jedn. Dz.U z 2013, poz. 267 ze zm.

32 Odmiennie J. Szachułowicz, który twierdzi, iż starosta wykonuje nadzór nad spółkami wodnymi na podstawie umocowania ustawowego i działa jako organ wykonujący zadania z zakresu administracji rządowej; J. Szachułowicz, op. cit., s. 432.

33 Ustawa z dnia 5 czerwca 1998 r. o samorządzie powiatowym, tekst jedn. Dz.U. z 2013 r., poz. 595 ze zm. 
(gminy, powiaty) lub województwu. Warunkiem dokonania takiego powierzenia jest podjęcie stosownych uchwał przez organy stanowiące jednostki przekazującej i przyjmującej zadanie oraz ogłoszenie porozumienia w sprawie powierzenia zadania w wojewódzkim dzienniku urzędowym ${ }^{34}$.

Ustawodawca w art. 178 p.w. przyjął, iż przedmiotem nadzoru jest działalność spółki wodnej. Oznacza to, że warunkiem sine qua non „uruchomienia” funkcji nadzorczych jest zaistnienie bytu prawnego spółki ${ }^{35}$. Nadzór ten rozpoczyna się więc wraz z rozpoczęciem działalności przez spółkę wodną i kończy wraz z zakończeniem tej działalności. Przyjmuję, iż działalnością objętą nadzorem starosty jest działalność spółki jako osoby prawnej. Wynika to m.in. z faktu, iż wobec podmiotu nieposiadającego osobowości prawnej („spółka w organizacji”) organ nie może stosować środków nadzorczych, dla których ustawodawca przewidział formę decyzji administracyjnej, gdyż kodeks postępowania administracyjnego nie dopuszcza możliwości przyznania statusu strony innym podmiotom aniżeli osoby fizyczne, osoby prawne, państwowe i samorządowe jednostki organizacyjne nieposiadające osobowości oraz organizacje społeczne. A contrario nie stanowią czynności nadzorczych działania organu administracji publicznej związane $\mathrm{z}$ utworzeniem spółki wodnej.

Ustawodawca na gruncie prawa wodnego nie przesądził in genere o kryterium nadzoru nad działalnością spółki wodnej, odnosząc je każdorazowo do przesłanek podjęcia konkretnego środka nadzorczego. Nie ulega wątpliwości, iż podstawowym kryterium nadzoru jest kryterium legalności (zgodności z prawem). Stanowi ono podstawę zastosowania takich środków nadzorczych jak stwierdzenie nieważności uchwały spółki (art. 179 ust. 2 p.w.), rozwiązania zarządu (180 ust. 1 p.w.), czy rozwiązania samej spółki (art. 181 ust. 2 pkt 1 p.w.). Należy jednocześnie wyraźnie wskazać, iż kryterium legalności, będące podsta-

34 Por. wyrok WSA w Gorzowie Wielkopolskim z 29 grudnia 2009 r., sygn. II SA/Go 888/09, Lex 582970.

35 Na temat momentu powstania spółki wodnej zob. B. Rakoczy, op. cit., wer. elektr. 
wą zastosowania przez starostę środków nadzorczych odnosi się zarówno do przepisów prawa powszechnie obowiązującego, jak i statutu spółki, co wynika expressis verbis z przepisów prawa wodnego. Powstaje jednocześnie pytanie, czy kryterium legalności jest wyłącznym kryterium nadzoru nad spółką wodną? Pytanie to jest szczególnie zasadne $\mathrm{w}$ odniesieniu do przyznanych staroście kompetencji do ingerowania w tak elementarną sferę funkcjonowania spółki wodnej, jaką są obowiązki partycypacji członków spółki w kosztach jej funkcjonowania. Zgodnie z art. 170 ust. 3 p.w. jeżeli uchwalone przez spółkę wodną zajmującą się utrzymaniem urządzeń melioracji wodnych szczegółowych składki i inne świadczenia nie wystarczają na wykonanie przewidzianych na dany rok zadań statutowych, starosta może wystąpić do organów spółki o podwyższenie wysokości tych składek i innych świadczeń, a jeżeli spółka wodna zajmująca się utrzymaniem urządzeń wykonanych przy udziale środków publicznych, mimo wystąpienia starosty, nie podjęła odpowiedniej uchwały, starosta może, w drodze decyzji, podwyższyć wysokość tych składek i innych świadczeń. Przyznane staroście kompetencje nie odnoszą się z całą pewnością do kryterium oceny legalności podjętych prze spółkę rozstrzygnięć w zakresie obciążeń członków spółki lecz do kryteriów celowości i gospodarności. Uznając, iż wynikająca z art. 170 ust. 3 p.w. kompetencja starosty stanowi realizację przypisanej mu funkcji nadzorczej, należy stwierdzić, iż przyjęte przez ustawodawcę kryteria nadzoru wykraczają poza kryterium legalności, co świadczy niewątpliwie o wysokim stopniu intensywności nadzoru.

\section{4. ŚRODKI NADZORU NAD SPÓŁKAMI WODNYMI}

Pod pojęciem środków nadzoru należy rozumieć formy ingerencji organów powołanych do nadzoru wobec podmiotów nadzorowanych ${ }^{36}$. Związanie administracji prawem, bę-

36 Por. P. Rączka, [w:] Z. Bukowski, T. Jędrzejewski, P. Rączka, Ustrój samorządu terytorialnego, Toruń 2011, s. 296. 
dące konsekwencją konstytucyjnej zasady legalności i praworządności, uzasadnia tezę o dopuszczalności stosowania przez organ nadzoru wyłącznie środków wyraźnie przewidzianych przepisami prawa. Zasada ta jest szczególnie istotna w związku z przyjęciem, iż pojęcie nadzoru samo w sobie nie zawiera treści odnoszących się do prawnej dopuszczalności podejmowania określonych działań. Oznacza to, iż zawarty w tekście prawny zwrot „sprawuje nadzór”, ,jest organem nadzoru” etc., nie wyznacza zakresu konkretnych działań organu nadzorującego wobec podmiotu nadzorowanego. Podstawy prawnej tychże działań należy poszukiwać w odrębnych normach prawnych o charakterze kompetencyjnym, zawartych w regulacji prawnej odnoszącej się do danego rodzaju stosunków społecznych. Jednym z podstawowych podziałów środków nadzoru, przyjętym w doktrynie prawa administracyjnego, jest wyodrębnienie środków kontroli i środków korygujących ${ }^{37}$. Zadaniem pierwszych $\mathrm{z}$ nich jest zapewnienie organom nadzorczym informacji o przestrzeganiu lub nieprzestrzeganiu prawa przez podmioty nadzorowane, a drugich - wywieranie wpływu na działania tych podmiotów $^{38}$. Analiza przepisów prawa wodnego pozwala przyjąć, iż podstawowym środkiem kontroli, realizowanym $\mathrm{w}$ ramach nadzoru nad spółką wodną, jest obowiązek przedkładanie staroście uchwał organów spółki. Obowiązek ten wynika expressis verbis z treści art. 179 ust. 1 p.w. i jest skierowany do zarządu spółki. Zakres obowiązku przedkładania uchwał organowi nadzoru obejmuje wszystkie uchwały organów spółki, a więc zarówno uchwały walnego zgromadzenia członków spółki, uchwały komisji rewizyjnej, a w przypadku zarządu wieloosobowego, również uchwały zarządu. Biorąc pod uwagę, iż powszechnie przyjmuje się, że organy monokratyczne podejmują swe rozstrzygnięcia $\mathrm{w}$ formie zarządzeń, a nie uchwał, opierając się na niebudzącej wątpliwości wykładni językowej przepisu, należy przyjąć, iż analizowany obowiązek nie dotyczy zarządzeń zarządu jednoosobowego. Jest to oczywista niekonsekwencja ustawodawcy, która musi zostać oceniona krytycznie. W orzecz-

38 Ibidem, s. 14. 
nictwie sądowym wskazano, iż zakres realizacji obowiązku przedłożenie uchwał spółki musi być skorelowany z wynikającym z art. 178 p.w. zakresem nadzoru. W ocenie sądu jedynie uchwały organów dotyczące działalności spółki jako formy organizacyjnej winny być w trybie określonym w art. 179 ust. 1 ustawy przedkładane staroście i tylko takie uchwały winien on kontrolować, a w razie stwierdzenia ich sprzeczności z prawem lub statutem orzekać w drodze decyzji o ich nieważności. Tym samym nie podlegają kontroli starosty, o której mowa powyżej te uchwały, które odnoszą się do wewnętrznych relacji pomiędzy spółką wodną a jej członkiem, wykraczają one bowiem poza pojęcie działalności, o której mowa w art. 178 ustawy ${ }^{39}$. Pogląd ten uważam za nieuzasadniony. Brak jest bowiem podstaw do przyjęcia, iż podejmowanie przez organy spółki rozstrzygnięć w formie uchwał nie mieści się w pojęciu działalności spółki wodnej, wyznaczającym zgodnie z art. 178 p.w., zakres sprawowanego nadzoru.

Zarząd ma obowiązek przedłożenia staroście uchwał spółki w ciągu 7 dni, od dnia ich podjęcia. Zaniechanie przez zarząd tego obowiązku może stanowić przesłankę zastosowania przez organ środka nadzorczego w postaci rozwiązania zarządu, na podstawie art. 180 ust. 1 p.w.

Drugą grupę środków nadzorczych stanowią środki korygujące, uznawane za środki nadzorcze sensu stricto, to jest takie, które umożliwiają organom nadzoru władczą ingerencję w działania podmiotu nadzorowanego. W rozdziale 3 działu VII prawa wodnego, zatytułowanym „nadzór i kontrola nad działalnością spółek" ustawodawca uregulował cztery takie środki, a mianowicie stwierdzenie nieważności uchwały organów spółki, wstrzymanie wykonania uchwały, odwołanie zarządu spółki oraz powołanie zarządu komisarycznego. Zgodnie z art. 179 ust. 2 p.w. uchwały organów spółek sprzeczne $\mathrm{z}$ prawem lub statutem są nieważne. Ustawodawca skutek nieważności uchwał powiązał z ich sprzecznością z prawem lub statutem. W logice przyjmuje się, iż dwa zdania są sprzeczne, gdy jedno z nich jest negacją

39 Wyrok WSA w Gliwicach z 20 lutego 2013 r., sygn. II SA/Gl 1096/12, CBOSA. 
drugiego. Ze sprzecznością uchwały z prawem będziemy więc mieli do czynienia wówczas, gdy treść uchwały stanowić będzie zaprzeczenie (negację) norm powszechnie obowiązującego prawa lub norm statutowych. Należy przyjąć, iż każda sprzeczność z prawem jest zarazem niezgodnością z prawem, natomiast nie każda niezgodność z prawem jest sprzecznością. Oznacza to, iż nie każde naruszenie prawa przez uchwałę organu spółki skutkuje jej nieważnością. Skutek ten powodować będzie wyłącznie takie naruszenie w konsekwencji, którego dojdzie do sprzeczności uchwały z prawem lub statutem, przy czym skutek ten nastąpi wówczas ex lege. Uprawnieniem nadzorczym starosty jest stwierdzenie nieważności uchwały sprzecznej z prawem lub statutem. Oznacza to, iż starosta $w$ ramach sprawowanego nadzoru, wyposażony został w kompetencje do władczego orzekania o bycie prawnym uchwał organów spółki. Orzeczenie starosty ma charakter deklaratoryjny i porządkowy ${ }^{40}$. Przyjęcie przez ustawodawcę, iż uchwała sprzeczna z prawem jest nieważna, oznacza że skutek nieważności istnieje od momentu jej podjęcia, a zadaniem organu nadzoru, realizowanym poprzez przysługujące mu kompetencje, jest wyeliminowanie przedmiotowej uchwały z obrotu prawnego. Stwierdzenie nieważności uchwały wywołuje więc skutek ex tunc. Oznacza ono, w istocie rzeczy, deklarację stanu prawnego (nieważności) ze względu na zaistnienie określonej przesłanki (sprzeczność aktu z prawem) przewidzianej przez ustawodawcę, z którą skutek taki prawo wiąż $\mathrm{e}^{41}$. Uprawnienia nadzorcze starosty zostały ograniczone czasowo, co uzasadnione jest potrzebą usunięcia stanu niepewności, związanej z podejmowanymi czynnościami nadzorczymi. Środek nadzoru, w postaci stwierdzenia nieważności uchwały, może zostać zastosowany w terminie 30 dni od dnia doręczenia uchwały staroście. W orzecznictwie sądowym, dotyczącym samorządu terytorialnego, ukształtowany jest pogląd, iż bieg

40 Por. postanowienie SN z 4 czerwca 2014 r., sygn. II CSK 453/13, www. sn.pl, postanowienie SN z 22 października 2014 r., sygn. II CSK 13/14, www. sn.pl.

41 Por. A. Matan, Ustawa o samorzadzie gminnym. Komentarz, red. B. Dolnicki, ABC 2010, wer. el. 
30-dniowego terminu na podjęcie środka nadzorczego w postaci stwierdzenia nieważności uchwały rozpoczyna się z dniem doręczenia organom nadzoru uchwały, a w przypadku zaniechania obowiązku ich przedłożenia termin ten nie biegnie ${ }^{42}$. Upływ 30-dniowego terminu powoduje wygaśnięcie kompetencji nadzorczych starosty do podjęcia środka nadzorczego - stwierdzenia nieważności uchwały. W ocenie sądów administracyjnych oznacza to, iż oświadczenie woli organu nadzoru zastosowania sankcji nieważności musi zostać uzewnętrznione przez doręczenie rozstrzygnięcia nadzorczego, najpóźniej w dniu w którym upływa ustawowy termin kompetencji nadzorczej ${ }^{43}$. W przeciwieństwie do ustaw samorządowych ${ }^{44}$, na gruncie ustawy prawo wodne, ustawodawca nie przyznał staroście wykonującemu funkcje nadzoru nad spółką wodną, po upływie terminu na podjęcie środka nadzorczego, prawa zaskarżenia uchwał tejże spółki, z powodu ich sprzeczności z prawem powszechnie obowiązującym lub statutem do sądu administracyjnego. Wynika to przede wszystkim z zakresu kognicji sądów administracyjnych. Zgodnie $\mathrm{z}$ art. $3 \S 1$ ustawy o postępowaniu przed sądami administracyjnymi ${ }^{45}$ sądy administracyjne sprawują kontrolę działalności administracji publicznej. Charakter prawny spółki wodnej oraz zakres realizowanych przez nią zadań nie pozwala zakwalifikować tej formy organizacyjnej do administracji publicznej w rozumieniu przywołanego przepisu. Szczegółowy katalog działań administracji, poddanych sądowej kontroli sądów administracyjnych określony został w art. $3 \S 2$ u.p.p.s.a. Wymienione

42 Wyrok WSA w Krakowie z dnia 17 czerwca 2014 r., sygn. II SA/Kr 526/14, LEX nr 1565750.

43 Wyrok NSA z dnia 7 listopada 2008 r., sygn. II OSK 1216/08; wyrok WSA w Gliwicach z dnia 18 lutego 2013 r., sygn. I SA/Gl 1417/12.

44 Ustawa z dnia 8 marca 1990 r. o samorządzie gminnym, tekst jedn. Dz.U z 2013 r., poz. 594 ze zm., ustawa z dnia 5 czerwca 1998 r. o samorządzie powiatowym, tekst jedn. Dz.U. z 2013 r., poz. 595 ze zm., ustawa z dnia 5 czerwca 1998 r. o samorządzie województwa, tekst jedn. Dz.U. z 2013 r., poz. 596 ze zm.

45 Ustawa z dnia 30 sierpnia 2002 r. Prawo o postępowaniu przed sądami administracyjnymi, tekst jedn. Dz.U. z 2012, poz. 270 ze zm., określa skrótem u.p.p.s.a. 
w tym przepisie formy działania, właściwe dla administracji publicznej, nie obejmują swym zakresem uchwał spółek wodnych.

Kolejnym środkiem nadzoru nad działalnością spółki wodnej jest wstrzymanie wykonalności uchwały organu spółki ${ }^{46}$. Zgodnie z art. 179 ust. 3 p.w. starosta, wszczynając postępowanie w sprawie stwierdzenia nieważności uchwały, może wstrzymać jej wykonanie. Wstrzymanie wykonania uchwały powoduje niedopuszczalność podejmowania na jej podstawie jakichkolwiek działań. Warunkiem zastosowania tego środka nadzoru jest wszczęcie postępowania w sprawie stwierdzenia nieważności uchwały. Biorąc pod uwagę fakt, iż na gruncie prawa wodnego rozstrzygnięcia nadzorcze podejmowane są w formie decyzji administracyjnej, oznacza to wszczęcie postępowania administracyjnego. Literalne brzmienie art. 179 ust. 3 p.w. skłania do wniosku, że jedynym momentem zastosowania analizowanego środka jest moment wszczęcia postępowania, co wykluczałoby możliwość jego podjęcia w toku tego postępowania ${ }^{47}$. Uważam jednak, iż wniosek taki jest racjonalnie nieuzasadniony. Wstrzymanie wykonania uchwały przez organ nadzoru ma charakter fakultatywny i zależy od uznania organu. Ustawodawca nie rozstrzygnął w jakiej formie organ nadzoru powinien wstrzymać wykonanie uchwały. Uwzględniając fakt, iż środek ten może zostać zastosowany wyłącznie w związku ze wszczęciem postępowania administracyjnego $\mathrm{w}$ sprawie stwierdzenia nieważności należy opowiedzieć się za formą postanowienia, przy czym na postanowienie to nie służy zażalenie. W ocenie A. Matana wstrzymanie wykonania uchwały znajduje zastosowanie tylko $\mathrm{w}$ trakcie prowadzonego postępowania nadzorczego, w związku z tym jego byt prawny zależy od zakończenia tego postępowania, a tym samym podjęcie rozstrzygnięcia nadzorczego (bez względu na jego treść) powoduje utratę mocy obowiązującej

$46 \mathrm{~W}$ ocenie J. Zimmermanna wstrzymanie wykonania uchwały przez organ nadzoru nie stanowi samodzielnego środka nadzorczego - J. Zimmermann, Elementy procesowe nadzoru i kontroli NSA nad samorzadem terytorialnym, „Państwo i Prawo” 1991, nr 10, s. 45.

47 Zgodnie z art. 91 ust. 2 ustawy z dnia 8 marca 1990 r. o samorządzie gminnym, organ nadzoru może wstrzymać uchwałę wszczynając postępowanie w sprawie stwierdzenia nieważności albo w toku tego postępowania. 
postanowienia wstrzymującego, bez konieczności formalnego stwierdzania jego wygaśnięcia ${ }^{48}$.

Kolejnym środkiem korygującym o charakterze represyjnym w jaki wyposażony został starosta sprawujący funkcję nadzoru nad działalnością spółki wodnej jest rozwiązanie zarządu i wyznaczenie osoby do pełnienia jego obowiązków. Środek ten ma charakter fakultatywny, a przesłanką jego zastosowania są powtarzające się naruszenia przez zarząd prawa lub statutu spółki. Kryterium „powtarzającego” się naruszenia jest kryterium nieostrym, mogącym sprawiać trudności interpretacyjne. W literaturze przedmiotu zaproponowano stanowisko, iż powtarzające się naruszenia mają miejsce już przy dwukrotnym ich wystąpieniu, z tym zastrzeżeniem, że powinny być to naruszenia tego samego charakteru i w tej samej sferze działalności zarządu ${ }^{49}$. Konsekwencją podjęcia rozstrzygnięcia nadzorczego o rozwiązaniu zarządu jest wyznaczenie przez starostę osoby do pełnienia obowiązków zarządu. Osoba ta, do czasu powołania nowego zarządu, wykonuje wszystkie obowiązki tego organu, a ponadto $\mathrm{w}$ terminie 3 miesięcy od dnia w którym decyzja o rozwiązaniu zarządu stała się ostateczna ma obowiązek zwołania walnego zgromadzenia w celu wybrania nowego zarządu. Zgodnie z art. 173 ust. 1 pkt 4 p.w. powołanie i odwołanie członków zarządu należy do wyłącznej kompetencji walnego zgromadzenia członków. Kompetencja ta wyznacza nie tylko sferę uprawnień organu ale również zakres jego obowiązków. Należy w związku z tym przyjąć, iż sytuacja w której walne zgromadzenie członków spółki nie dokonuje wyboru zarządu, jest sytuacją niezgodną z prawem. W ocenie ustawodawcy stan taki uzasadnia przyznanie organom nadzoru kompetencji w zakresie skorygowania zaistniałych nieprawidłowości w funkcjonowaniu spółki. Środkiem służącym realizacji tego celu jest ustanowienie przez organ nadzoru zarządu komisarycznego. Zarząd komisaryczny może zostać ustanowiony wyłącznie wówczas, gdy walne zgromadzenie członków nie dokona wyboru zarządu, w związku z uprzednim zastosowaniem

48 A. Matan, op. cit., wer. el.

49 J. Szachułowicz, op. cit., s. 435. 
przez organ nadzoru środka nadzorczego w postaci rozwiązania zarządu na skutek stwierdzenia powtarzającego się naruszenia prawa przez ten organ.

Przedstawione powyżej kompetencje starosty do władczej ingerencji w sferę działalności spółki wodnej zostały expressis verbis przyporządkowane instytucji nadzoru nad działalnością spółki poprzez ich uregulowanie w rozdziale zatytułowanym „nadzór i kontrola nad działalnością spółki”. Nie są to jednak wszystkie kompetencje $\mathrm{w}$ jakie wyposażony został ten organ w stosunku do spółki wodnej. Powstaje w związku z tym pytanie, czy omówione powyżej środki nadzoru wyczerpują katalog uprawnień nadzorczych starosty w analizowanej relacji. Na tak postawione pytanie $\mathrm{w}$ mojej ocenie należy udzielić odpowiedzi negatywnej. Uważam, iż co najmniej jeszcze dwa instrumenty prawne stanowią w swej istocie środki nadzorcze nad działalnością spółki wodnej. Jest to rozwiązania spółki w drodze decyzji administracyjnej oraz podwyższenia wysokości składek oraz innych świadczeń, na podstawie art. 170 ust. 3 p.w.

Spółka wodna będąca dobrowolnym zrzeszeniem osób dążących do osiągnięcia celów w postaci zaspokojenia potrzeb swoich członków w zakresie gospodarowania wodami co do zasady ulega rozwiązaniu na skutek woli tych członków wyrażonej w drodze uchwały walnego zgromadzenia. Poza tą, rzec by można, „naturalną”, formą rozwiązania spółki ustawodawca dopuścił możliwość zakończenia jej bytu prawnego na skutek władczego rozstrzygnięcia organu administracyjnego - starosty. Rozstrzygnięcie to może zostać podjęte w trzech sytuacjach: 1) działalność spółki narusza prawo lub statut, 2) upłynął termin, na jaki został ustanowiony zarząd komisaryczny, o którym mowa w art. 180 ust. 3 p.w., a walne zgromadzenie nie dokonało wyboru nowego zarządu, 3) liczba członków jest mniejsza niż określona w art. 165 ust. 1 p.w. Pomimo tego, iż ustawodawca w pierwszym z wymienionych przypadków odwołał się wprost do stanu naruszenia prawa działalnością spółki również w dwóch pozostałych przypadkach, z naruszeniem takim mamy do czynienia. Przyjmuję w związku z tym, iż przyznana staroście kompetencja do rozwiązania spółki wodnej stanowi środek 1/2015 nadzoru nad spółką, którego zastosowanie determinowane jest 
kryterium legalności. Jednocześnie w katalogu środków nadzorczych jest to środek najbardziej dotkliwy, skutkujący ustaniem bytu prawnego podmiotu nadzorowanego. Oparcie kompetencji organu nadzoru na normie uznaniowej („organ może”) stwarza po stronie organu szczególny obowiązek rozważenia i wyważenia wszelkich występujących w sprawie interesów ${ }^{50}$.

Do środków nadzoru nad działalnością spółki zaliczam również przyznane staroście prawo zwrócenia się do spółki o podwyższenie składek i innych świadczeń na rzecz spółki oraz dokonanie podwyższenia tych świadczeń. Jedną z zasad funkcjonowania spółek wodnych jest zasada partycypacji członków spółki w kosztach jej funkcjonowania poprzez wnoszenie na rzecz spółki składek i ponoszenia innych określonych w statucie świadczeń. Składki i inne świadczenia powinny być ponoszone w wysokości i zakresie niezbędnym do wykonywania statutowych zadań spółki. W związku z powyższym ustawodawca przyznał staroście sprawującemu nadzór nad spółką, prawo wystąpienia do spółki o podwyższenie wysokości składek i innych świadczeń w przypadku, gdy uchwalone przez spółkę wodną zajmującą się utrzymaniem urządzeń melioracji wodnych szczegółowych składki i inne świadczenia nie wystarczają na wykonanie przewidzianych na dany rok zadań statutowych. Przyznana staroście kompetencja ma charakter uprawnienia sygnalizacyjnego. Jednakże w przypadku, gdy spółka wodna zajmująca się utrzymaniem urządzeń wykonanych przy udziale środków publicznych, mimo wystąpienia starosty, nie podjęła odpowiedniej uchwały, starosta może, w drodze decyzji, podwyższyć wysokość tych składek i innych świadczeń. Podjęcie przez organ nadzoru władczych działań korygujących zostało, w stosunku do uprawnień sygnalizacyjnych, ograniczone wyłącznie do przypadków, gdy urządzenia wodne będące w utrzymaniu spółki wodnej zostały wykonane przy udziale środków publicznych. Oznacza to, że nie w każdym przypadku gdy starosta sygnalizował konieczność podwyższenia składek lub innych świadczeń a organy

50 Szerzej na temat rozwiązania spółki wodnej: K. Kierzkowska, Rozwiązanie spótki wodnej w prawie polskim, „Przegląd Prawa Ochrony Środowiska” 2012, Nr 2, s. 9 i n. 
spółki nie podjęły stosowanej uchwały możliwa będzie władcza ingerencja $\mathrm{w}$ działalność spółki, polegająca na podwyższeniu składek i innych świadczeń w trybie administracyjnym. Zastosowanie środków nadzoru w postaci sygnalizacji konieczności podwyższenia składek oraz podwyższenia tych składek w trybie administracyjnym nie jest determinowane kryterium legalności lecz kryterium celowości i gospodarności. Organ nadzoru nie weryfikuje działalności podmiotu nadzorowanego przez pryzmat zgodności jego zachowań z prawem lecz w odniesieniu do celu jaki ma osiągnąć spółka oraz konieczności zabezpieczenia racjonalności wydatkowania środków publicznych.

Przepisy prawa wodnego przyznają ponadto staroście kompetencje do władczego rozstrzygania $\mathrm{w}$ przedmiocie zatwierdzenia statutu spółki wodnej oraz w przedmiocie wysokości i rodzaju świadczeń podmiotów nie będących członkami spółki wodnej odnoszących korzyści z urządzeń spółki lub przyczyniających się do zanieczyszczania wody, dla której ochrony spółka została utworzona. Kompetencje te w mojej ocenie nie zawierają się jednak w funkcji nadzoru nad działalnością spółki i jako takie nie stanowią środków nadzorczych. Zarówno w jednym, jak i w drugim przypadku adresatem podejmowanych rozstrzygnięć nie jest spółka wodna. W przypadku zatwierdzenia statutu stroną toczącego się postępowania, a w konsekwencji i rozstrzygnięcia, są osoby zainteresowane utworzeniem spółki. Kompetencje starosty do zatwierdzenia statutu spółki oraz związany z tym zatwierdzeniem skutek w postaci nabycia przez spółkę osobowości prawnej są wyrazem administracyjnoprawnej reglamentacji procesu tworzenia spółek wodnych, a nie nadzoru nad tymi spółkami. W przypadku decyzji ustalającej wysokość i rodzaje świadczeń dla podmiotów nie będących członkiem spółki organ administracyjny w sposób władczy wkracza w sferę praw i obowiązków osób nie związanych ze spółką więziami organizacyjnymi, nakładając na te osoby obowiązek partycypowania w kosztach funkcjonowania spółki.

Formą podejmowania rozstrzygnięć nadzorczych nad spółką wodną jest decyzja administracyjna. Pomimo wprowadzenia jednolitej formy władczych działań nadzorczych ustawodawca, poprzez szczegółowe regulacje prawne, wprowadził daleko 
idące odrębności decyzji w sprawie stwierdzenia nieważności uchwał spółki wodnej w stosunku do pozostałych rozstrzygnięć nadzorczych. W przypadku decyzji stwierdzającej nieważność uchwał ustawodawca odstąpił od zasady dwuinstancyjności postępowania administracyjnego, przyjmując iż decyzja starosty jest decyzją ostateczną. Jednocześnie ustawodawca przyznał spółce wodnej prawo do skorzystania $\mathrm{z}$ niedewolutywnego środka prawnego w postaci wniosku o ponowne rozpoznanie sprawy. Należy stwierdzić, iż rozwiązanie takie pozostaje, od 11 kwietnia 2011 r., w sprzeczności z art. $16 \$ 1$ kpa. Zgodnie z tym przepisem, w brzmieniu nadanym ustawą z 3 grudnia 2010 r. $^{51}$ decyzje, od których nie służy odwołanie w administracyjnym toku instancji lub wniosek o ponowne rozpatrzenie sprawy, są ostateczne. A contrario decyzje na które przysługuje wniosek o ponowne rozpoznanie sprawy ostateczne nie są. Uważam, iż brak jest racjonalnych podstaw do różnicowania przymiotu ostateczności decyzji administracyjnej na gruncie przepisów kpa i prawa wodnego, a zaistniałą sytuację przypisuję niedopatrzeniu ustawodawcy, który nie dostosował przepisów proceduralnych zawartych w ustawach szczegółowych, w tym w prawie wodnym, do zmian wprowadzonych w kodeksie postępowania administracyjnego. Pozostałe rozstrzygnięcia nadzorcze starosty zapadają w formie „typowej” decyzji administracyjnej wydawanej na podstawie przepisów kpa.

\section{5. ŚRODKI OCHRONY PRAWNEJ PODMIOTÓW NADZOROWANYCH ORAZ CZŁONKÓW SPÓŁKI WODNEJ}

Stosowanie środków nadzorczych, będące w swej istocie władczą ingerencją państwa w sferę działalności podmiotów nadzorowanych, musi w demokratycznym państwie prawnym być powiązane z gwarancją ochrony interesów podmiotów

51 Ustawa z 3 grudnia 2010 r. o zmianie ustawy - Kodeks postępowania administracyjnego oraz ustawy - Prawo o postępowaniu przed sądami administracyjnymi, Dz.U. z 2011 r., Nr 6 poz. 18. 
nadzorowanych wynikającą z wyposażenia tych podmiotów w środki prawne służące skutecznej obronie ich praw. Przyjęcie, na gruncie prawa wodnego, formy decyzji administracyjnej dla rozstrzygnięć nadzorczych, stwarza podmiotom nadzorowanym gwarancje procesowe właściwe procedurze administracyjnej ochrony interesów adresatów władczych rozstrzygnięć, którym w przypadku rozstrzygnięć nadzorczych jest co do zasady spółka wodna. Oznacza to, że spółka wodna ma prawo kwestionowania rozstrzygnięć nadzorczych poprzez środki prawne właściwe procedurze administracyjnej, to jest: odwołanie, wniosek o ponowne rozpoznanie sprawy, wniosek o wznowienie postępowania, wniosek o stwierdzenie nieważności. Zgodnie z zasadą sądowej kontroli administracji publicznej, po wyczerpaniu administracyjnych, zwyczajnych środków weryfikacji decyzji, spółce przysługuje również prawo zaskarżenia decyzji starosty do sądu administracyjnego. Szczególnym rozwiązaniem przyjętym na gruncie prawa wodnego jest odstąpienie przez ustawodawcę od zasady dwuinstancyjności w przypadku decyzji stwierdzającej nieważność uchwały organu spółki. Zgodnie z art. 179 ust. 4 p.w. decyzja o stwierdzeniu nieważności uchwały jest ostateczna; spółka wodna, której uchwała została uchylona, może zwrócić się do starosty z wnioskiem o ponowne rozpatrzenie sprawy, a po wyczerpaniu tego trybu spółce wodnej przysługuje skarga do sądu administracyjnego. Przepis ten, w swej drugiej części, zawiera oczywisty błąd, gdyż starosta posiada kompetencje do stwierdzenia nieważności uchwały, a nie do jej uchylenia.

W ocenie WSA w Lublinie w związku z tym, iż w kompetencji nadzorczej starosty nad działalnością spółek wodnych nie mieści się uchylenie uchwały, a jedynie stwierdzenie jej nieważności, użyte w art. 179 ust. 4 p.w. sformułowanie „uchwała została uchylona” uznać należy za synonim „stwierdzenia nieważności uchwały". Zatem, ostateczną decyzję starosty w przedmiocie stwierdzenia nieważności uchwał walnego zgromadzenia spółki wodnej, można zakwestionować w drodze wniosku o ponowne rozpatrzenie sprawy, a następnie, po wyczerpaniu trybu 1/2015 administracyjnego, w drodze skargi do wojewódzkiego sądu ad- 
ministracyjnego ${ }^{52}$. Odmienny pogląd wyraziły natomiast WSA w Łodzi i Szczecinie, zdaniem których z literalnego brzmienia art. 179 ust. 4 p.w. wynika, że spółce wodnej przysługuje prawo zwrócenia się do starosty $\mathrm{z}$ wnioskiem o ponowne rozpatrzenie sprawy tylko wówczas, gdy uchwała spółki na mocy decyzji starosty została uchylona. Dopiero po wyczerpaniu tego trybu spółce wodnej służy skarga do sądu administracyjnego. Tryb wewnętrznej kontroli decyzji przez starostę, nie ma w ocenie sądu, zastosowania w przypadku decyzji starosty stwierdzającej nieważność uchwały spółki wodnej. Takiej decyzji ustawodawca nadał bowiem przymiot ostateczności, której skutkiem jest przyznanie stronie niezadowolonej z rozstrzygnięcia prawa do jego zaskarżenia do sądu administracyjnego w terminie przewidzianym $\mathrm{w}$ art. $53 \S 1$ u.p.p.s.a. ${ }^{53} \mathrm{~W}$ pełni przychylam się do stanowiska WSA w Lublinie. Pogląd wyrażony w orzeczeniu WSA w Szczecinie jest bezzasadny w świetle braku ustawowej kompetencji starosty, jako organu nadzoru, do uchylenia uchwały organów spółki wodnej. Z wyraźnej woli ustawodawcy prawo kwestionowania rozstrzygnięć $\mathrm{w}$ przedmiocie stwierdzenia nieważności uchwał spółki zostało ograniczone podmiotowo wyłącznie do samej spółki. Oznacza to, że inne, poza spółką wodną, podmioty, w tym członkowie spółki, nie mają prawa występowania do starosty $\mathrm{z}$ wnioskiem o ponowne rozpatrzenie sprawy oraz ze skargą do sądu administracyjnego, niezależnie od posiadanego interesu prawnego.

W przypadku pozostałych środków nadzorczych (rozwiązanie zarządu, ustanowienie zarządu komisarycznego, rozwiązanie spółki, podwyższenie wysokości składek lub innych świadczeń członka spółki) zarówno spółka, jak i inne osoby posiadające interes prawny mają prawo wniesienia odwołania od decyzji starosty do organu wyższego stopnia, według ogólnych reguł kodeksu postępowania administracyjnego. Organem wyż-

52 Wyrok WSA w Lublinie z 20 maja 2008 r., sygn. II SA/Lu 186/08, Lex 500767.

53 Postanowienie WSA w Łodzi z 7 października 2008 r., sygn. II SA/Łd 446/08, Lex 504536 i wyrok WSA w Szczecinie z 30 stycznia 2014 r., sygn. II SA/Sz 931/13, Lex 1435399. 
szego stopnia, w rozumieniu przepisów kpa, jest w tych sprawach samorządowe kolegium odwoławcze ${ }^{54}$. Po wyczerpaniu administracyjnego toku instancji, podmiotom posiadającym $\mathrm{w}$ tym interes prawny, przysługuje prawo wniesienia skargi do sądu administracyjnego.

Jednym z istotnych zagadnień, jakie pojawiły się w orzecznictwie sądów administracyjnych, w związku z instytucją nadzoru nad spółką wodną, jest kwestia dopuszczalności skargi na bezczynność organów nadzoru. W tym miejscu należy przypomnieć, iż na organie nadzoru ciąży obowiązek stwierdzenia nieważności uchwały sprzecznej z prawem. W przypadku pozostałych środków nadzorczych mają one charakter uznaniowy. W związku z powyższym powstaje pytanie, czy członek spółki wodnej lub inny zainteresowany podmiot może domagać się od organów nadzoru podjęcia czynności nadzorczych w postaci stwierdzenia nieważności uchwały spółki wodnej, a w przypadku bierności organu nadzoru wnieść skargę na jego bezczynność? W orzecznictwie sądowym ukształtował się pogląd negujący dopuszczalność zaskarżenia bezczynności organu nadzoru. $\mathrm{U}$ jego podstaw legła, wynikająca z istoty nadzoru, koncepcja działania organu nadzoru z urzędu ${ }^{55}$.

\section{NADZÓR ADMINISTRACYJNY A KOGNICJA SĄDÓW POWSZECHNYCH}

Objęcie spółek wodnych nadzorem organów administracji publicznej wynika ze specyfiki zadań realizowanych przez te podmioty oraz związanej z tym potrzeby ochrony interesu publicznego. Poddanie spółki wodnej nadzorowi administracyjne-

54 Por. postanowieni NSA z 12 stycznia 2012, sygn. II OW 125/11, LEX 1125530. Odmiennie J. Szachułowicz, op. cit., s. 436.

55 Por. wyrok WSA w Gliwicach z 30 czerwca 2010 r., sygn. II SAB/Gl 22/10, CBOSA; postanowienie WSA w Krakowie z 22 grudnia 2009 r., sygn. II SAB/Kr 72/09, CBOSA; wyrok NSA z 17 maja 2012, sygn. II OSK 489/12, Lex 1252088. 
mu w żadnym wypadku nie może przesądzać o administracyjnoprawnym charakterze samego podmiotu nadzorowanego, ani też uzasadniać prób lokowania tego podmiotu w strukturach administracji publicznej. Spółka wodna będąc dobrowolnym zrzeszeniem jej członków opiera swą działalność na stosunkach zobowiązaniowych, wynikających z porozumienia o utworzeniu spółki. Należy w związku z tym przyjąć, iż stosunek członkostwa w spółce wodnej jest stosunkiem cywilnoprawnym i jako taki podlega ochronie sądów powszechnych ${ }^{56}$. Powstaje w związku z tym pytanie czy sądy powszechne są związane rozstrzygnięciami organów nadzoru, czy też są uprawnionego do podejmowania samodzielnych ustaleń np. w zakresie ważności uchwał organów spółki oraz wynikających z nich skutków prawnych. W orzecznictwie Sądu Najwyższego przyjęto, iż decyzja starosty o zatwierdzeniu statutu spółki ma charakter konstytutywny i jako taka wiąże sąd co do skutku prawnego nabycia osobowości prawnej przez spółkę wodną. Nie zwalnia to jednak sądu z dokonywania w konkretnej sprawie oceny, czy statut nie zawiera postanowień sprzecznych $\mathrm{z}$ ustawą i jako takich nieważnych (art. $58 \S 1$ i 3 k.c.) ${ }^{57}$. Należy w związku z tym przyjąć, że również w przypadku innych uchwał sądowi przysługuje uprawnienie do kontroli in casu ich zgodności z ustawą, jeżeli uchwały te mają charakter czynności prawnych, przy czym możliwości tej nie wyłącza kompetencja starosty do wszczęcia $\mathrm{w}$ tym przedmiocie postępowania administracyjnego na podstawie art. 179 p.w. Uprawnienia sądu w tym zakresie mają charakter ustrojowy więc niemożność ich wykonywania musiałaby wynikać z wyraźnej woli ustawodawcy, a takich wyłączeń w prawie wodnym brak ${ }^{58}$.

56 Zob. postanowienie SN z 31 sierpnia 1965 r., sygn. II CZ 60/65, OSNCP 1966, nr 7-8, poz. 118, postanowienie SN z 11 sierpnia 2004 r., sygn. II CK 481/03, „Izba Cywilna” 2005, nr 3, s. 54, postanowienie SN z 13 września 2007 r., sygn. III CZP 80/07, www.sn.gov.pl, postanowienie SN z 3 lipca 2008 r., sygn. IV CZ 48/08, ww.sn.gov.pl.

57 Postanowienie SN z 29 czerwca 2010 r., sygn. III CZP 46/10, OSNC 2011, Nr 2, poz. 18.

58 Postanowienie SN z 4 czerwca 2014 r., sygn. II CSK 453/13, Lex 1514731. 


\section{WNIOSKI KOŃCOWE}

Spółki wodne jako podmioty zaangażowane w realizację zadań i celów publicznych poddane zostały nadzorowi administracyjnemu realizowanemu przez starostów. Nadzór ten polega na prawnie dopuszczonej możliwości podjęcia wobec spółki wodnej środków nadzorczych o charakterze kontrolnym lub korygującym. Środki o charakterze korygującym stanowią władczą ingerencję organu nadzorczego w działalność spółki wodnej zmierzającą do usunięcia stanu niezgodnego z prawem. Poddanie spółki wodnej nadzorowi administracyjnemu, postrzegane przez przedstawicieli doktryny jako charakterystyczna cecha tej formy organizacyjnoprawnej ${ }^{59}$, stanowi przejaw administracyjnoprawnej reglamentacji wolności zrzeszania się, wynikającej z ustawowych celów działalności spółki wodnej związanych $\mathrm{z}$ ich udziałem w gospodarowaniu wodami. Pomimo uregulowania nadzoru nad spółkami wodnymi w prawie wodnym, stanowiącym źródło materialnego prawa administracyjnego, nadzór ten nie stanowi nadzoru prawa materialnego. Uprawnienie do podejmowania działań skutkujących ingerencją wynika z zależności funkcjonalnej spółek wodnych od administracji, związanej z wykonywaniem zadań publicznych, korzystaniem ze środków publicznych oraz z ustawowego upoważnienia podmiotu nadzorującego do nakładania obowiązków lub innego ograniczania swobody działania na podstawie normy stanowiącej o zakresie działania organu administracyjnego ${ }^{60}$. Szczegółowa analiza przepisów prawa wodnego dotyczących nadzoru nad spółkami wodnymi, uzasadnia tezę o niezadawalającym stanie regulacji prawnej w tym zakresie. Mnożące się wątpliwości interpretacyjne, nieuzasadnione odstępstwa od przyjętych konstrukcji prawnych, luki w prawie nie sprzyjają prawidłowemu stosowaniu analizowanych przepisów. Szczególnie krytycznie należy odnieść się do braku odpowiednich regulacji prawnych gwarantu-

59 J. Rotko, [w:] Prawo wodne. Komentar\%, red. J. Rotko, Wrocław 2002, s. 409.

60 M. Szewczyk, op. cit., s. 45. 
jących ochronę praw członków spółki wyrażającą się w prawie „zaskarżenia” uchwał organów spółki, prawie żądania podjęcia czynności nadzorczych, czy prawie do kwestionowania rozstrzygnięć organów nadzoru.

\section{BIBLIOGRAFIA}

Bar L., Elementy administracyjne $w$ kierowaniu gospodarka narodowa, [w:] Instytucje prawne $w$ gospodarce narodowej, red. L. Bar, Warszawa 1981.

Bigo T., Z problemów kontroli nad administracją terenową, „Kontrola Państwowa" 1964, Nr 1.

Bocheński T., Gebert S., Służewski J., Rady narodowe i terenowe organy administracji państwowej, Warszawa 1977.

Bukowski Z., Jędrzejewski T., Rączka P., Ustrój samorządu terytorialnego, Toruń 2011.

Dawidowicz W., Polskie prawo administracyjne, Warszawa 1978.

Dawidowicz W., Zagadnienia ustroju administracji państwowej $w$ Polsce, Warszawa 1970.

Homplewicz J., Ogólne zagadnienia prawne kontroli administracji, „Kontrola Państwowa” 1965, Nr 4.

Jagielski J., Kontrola administracji publicznej, Warszawa 2006.

Jaroszyński A., Nadzór nad radami narodowymi i administracją terenowa, „Rada Narodowa, Gospodarka, Administracja” 1983, Nr 18.

Jędrzejewski S., Zakres pojęcia „nadzór" $w$ doktrynie prawa administracyjnego, [w:] Administracja publiczna u progu XXI wieku, przew. kom. red. Z. Niewiadomski, Przemyśl 2000.

Kierzkowska K., Rozwiązanie spótki wodnej w prawie polskim, „Przegląd Prawa Ochrony Środowiska" 2012, Nr 2.

Leoński Z., Nadzór nad działalnością gminy, Warszawa 1991.

Możdżeń-Marcinkowski M., Nadzór właścicielski Skarbu Państwa $w$ systemie kontroli administracji publicznej-zarys problematyki, [w:] Koncepcja systemu prawa administracyjnego, red. J. Zimmermann, Warszawa 2007.

Ochendowski E., Prawa administracyjne. Czesść ogólna, Toruń 2013.

Paczuski R., Spótki wodne - cele, zadania, prawne podstawy organizacji oraz perspektywy ich rozwoju w kontekście zachodzacych zmian, Toruń 2006. 
Paczuski R., Spótki wodne. Historia, prawne podstawy działania, nowe tendencje, Warszawa 1989.

Prawo administracyjne, red. J. Boć, Wrocław 1993.

Prawo wodne. Komentarz, red. B. Rakoczy, Lex 2013.

Rabska T., Podstawowe pojęcia organizacji administracji, [w:] System prawa administracyjnego, t. I, red. J. Starościak, Wrocław 1977.

Rączka P., Nadzór nad samorządem zawodowym, Toruń 1999.

Rybicki Z., Piątek S., Zarys prawa administracyjnego i nauki administracji, Warszawa 1984.

Starościak J., Decentralizacja administracji, Warszawa 1960.

Szachułowicz J., Prawo wodne. Komentarz, Warszawa 2010.

Szewczyk M., Nadzór w materialnym prawie administracyjnym, Poznań 1996.

Ustawa o samorzadzie gminnym. Komentarz, red. B. Dolnicki, ABC 2010, wer. el.

Wacinkiewicz D., Kontrola i nadzór w prawie komunalnym, Warszawa 2007.

Wierzbowski M., Wiktorowska A., Podstawowe pojęcia teoretyczne $w$ nauce prawa administracyjnego, [w:] Polskie prawo administracyjne, red. J. Służewski, Warszawa 1992.

Zimmermann J., Elementy procesowe nadzoru i kontroli NSA nad samorządem terytorialnym, „Państwo i Prawo” 1991, nr 10.

Kontakt e-mail:

szalew@law.umk.pl 